\title{
RAPID IDENTIFICATION FOR SEROTYPING OF AFRICAN SWINE FEVER VIRUS BASED ON THE SHORT FRAGMENT OF THE EP402R GENE ENCODING FOR CD2-LIKE PROTEIN
}

\author{
TRAN Ha Thi Thanh, TRUONG Anh Duc, LY Duc Viet, HOANG Tuan Van, \\ NGUYEN Chinh Thi, CHU Nhu Thi, NGUYEN Huyen Thi, DANG Hoang Vu* \\ Department of Biochemistry and Immunology, National Institute of Veterinary Research, 86 Truong \\ Chinh, Dong Da, Hanoi 100000, Vietnam
}

(Received 28 October, Accepted 31 December 2020)

\begin{abstract}
The first confirmed case of African swine fever (ASF) in Vietnam was officially reported in February 2019. To date, the ASF virus (ASFV) has been detected in all 63 cities/provinces in Vietnam. In order to get a better understanding of the potential role of the EP402R gene in a grouping of ASFV serotypes, thirty ASFV sequences of EP402R genes (accession numbers: MN711757-86) from North Central Coast of Vietnam and 68 well-known references of serotype groups from previous studies were further analyzed. Interestingly, we found that a short fragment of 90 nucleotides was very typical for 8 serological groups of ASFVs. A primer set was designed to amplicon the short fragment of 90 nucleotides using the Primer3 program to establish a simplified method for the serotyping of ASFV. Our results indicated that phylogenetic analysis of the short fragment ( 90 nucleotides) of the EP402R gene is a very specific and useful method for ASFV serotyping when compared to the previous method using a long fragment (816 nucleotides) of this gene and well-known serotype references based on haemadsorption inhibition (HAI) assay.
\end{abstract}

Keywords: African Swine Fever Virus, Serotyping, EP402R gene, CD2v, Vietnam

\section{INTRODUCTION}

Since the first ASF outbreak in China in 2018, the disease has spread to some countries in Asia and the Pacific, including Mongolia, Vietnam, Cambodia, Korea, Laos, Myanmar, Philippines, Timor-Leste, Papua New Guinea and Indonesia. The first case of ASF outbreak in Vietnam was officially reported in February 2019, and to date, the disease has spread in 63/63 provinces/cities of Vietnam. Approximately six million pigs have been culled in infected farms, suggesting the risk of spreading of this virus. Many active measures were conducted by Vietnamese Government to inhibit the rapid spread of ASF virus. In a previous study, we have indicated that ASFVs isolated

\footnotetext{
*Corresponding author: e-mail: vet.biochem.immuno@nivr.gov.vn or dangnivr@yahoo.com
} 
from 30 clinical samples in North Central Coast of Vietnam belonged to genotype II, serotype 8 and contained additional tandem repeat sequences between the I73R and the I329L protein genes [1]. All sequences have been deposited to GenBank with accession numbers as MN711727-56 for p72 genes, MN711757-86 for EP402R genes and MN733925-54 for TRS genes. Similarly, the data obtained from an ASFV isolated in the Red River Delta of Vietnam also indicated that this field strain belongs to genotype II and serotype 8 [2], suggesting that ASFVs circulating in Vietnam are very close to Eastern European and Chinese strains. Additionally, recent reports suggested that the updates of research methods based on current databases of ASFV sequences are very important for ASFV diagnosis, genotyping and serotyping $[3,4]$.

To date, at least eight ASFV serogroups have been reported and some previous studies have suggested that ASF protective immunity appears to be serotype-specific. Additionally, it has been indicated that serotyping of ASFV is very important for vaccine design and development. Currently, two methods have been developed for grouping of ASFV serotypes, including HAI (haemadsorption inhibition) assay and long fragment PCR based on sequencing method developed by Sanna [5]. However, HAI assay has shown a disadvantage in which this method may not apply in the cases of non-haemadsorbing ASFV viruses, suggesting that PCR based on sequencing method is a good candidate for serotyping of ASFV [6,7]. ASFV serotyping method based on a long fragment (816 nucleotides) of EP402R gene has been first described in 2017 [5]. The primer set for this PCR sequencing method was designed based on genotype I sequences and some previous studies have indicated their successes when using this system for ASFV serotyping $[5,8,9]$. In order to get a better understanding of the potential role of EP402R gene in grouping of ASFV serotypes, thirty sequences of EP402R genes (accession numbers: MN711757-86) were further analyzed. Interestingly, we found that a short fragment of 90 nucleotides was very typical for 8 serological groups of ASFVs. Thus, in this study, we established a simplified method for ASFV serotyping based on the short fragment of 90 nucleotides of EP402R gene coding for CD2-like protein.

\section{MATERIALS AND METHODS}

\section{Virus isolation}

The porcine alveolar macrophages (PAM) cultures used for the isolation of the virus were derived from domestic pigs that were tested negative for ASFV upon diagnosis with conventional PCR as previously described [3,10], and according to the recommendation by the World Organization for Animal Health [10]. Briefly, these cells were obtained and resuspended in Dulbecco's modified Eagle's medium (DMEM, Thermo Fisher Scientific) supplemented with streptomycin (Sigma-Aldrich), ampicillin (Sigma-Aldrich) and 5\% fetal calf serum (FCS, Sigma-Aldrich) to a final concentration of $1 \times 10^{6}$ cells $/ \mathrm{mL}$. Six-well culture plate (Thermo Scientific), containing $2 \mathrm{~mL}$ of the cell suspension, were inoculated with $50 \mu \mathrm{L}$ of a clarified $10 \%$ spleen or lymph 
node suspension. After three days of incubation at $37^{\circ} \mathrm{C}$, in an atmosphere with $5 \%$ $\mathrm{CO}_{2}$, the first passage virus was harvested by freezing and thawing. For the second passage, $50 \mu \mathrm{L}$ of this virus harvest was added to $2 \mathrm{~mL}$ fresh PAMs, then incubated and harvested as described for the first passage. For the third passage, $50 \mu \mathrm{L}$ of this virus harvest was added to $2 \mathrm{~mL}$ fresh PAMs, then incubated at $37^{\circ} \mathrm{C}$, in an atmosphere with $5 \% \mathrm{CO}_{2}$. After one-day incubation, a $20-\mu$ l preparation of $1 \%$ homologous red blood cells (RBC) in buffered saline was added to each well. The plates were examined for HAD and cytopathic effects over a 4-day period in PAM cells according to the recommendation by World Organization for Animal Health [10].

\section{Conventional PCR method}

TheDNA of ASFV were extracted from infected pig-organ samples using PureLink Viral RNA/DNA Mini Kit (Invitrogen, Carlsbad, CA, USA) as given by the manufacturer's instructions. Conventional PCR were performed to amplify the partial gene CD2v (CP204L) gene from Vietnam ASFV strains using the specific primer set CD2-2F and 2R, to amplify a 816-bp fragment of EP402R gene coding for the cytoplasmic portion of CD2-like protein as described previously $[5,11]$. In the second conventional PCR, we designed a set of primers to amplify of short fragment CDS of CD2v gene, named CD2v-F1 (5'-AT'T'T'TCCTCATAATGATGTATT'TGAT-3', binding site 73,644 -73,670) and CD2v-R1 (5'-TGATAT'TTGGGGGAGTAGCAGG-3', binding site 73,729-73,751), to amplify a 107-bp fragment of EP402R gene. Primer binding sites were based on the comparison of the genome of the ASFV from China (MK333180.1), Vietnam (MN711757-86), Georgia (FR682468), Russia (KM609342) and Belgium (MK543947). PCR was carried out in Agilent PCR System (Agilent, Santa Clara, CA, USA) using Taq polymerase (Thermo Scientific, Waltham, MA USA), according to the manufacturer's instructions. Thermal conditions for performing PCR are as follows: an initial incubation at $95^{\circ} \mathrm{C}$ for $10 \mathrm{~min}$; 40 cycles of denaturation at $95^{\circ} \mathrm{C}$ for $15 \mathrm{~s}$, annealing at $58^{\circ} \mathrm{C}$ for $30 \mathrm{~s}$, and extension at $72^{\circ} \mathrm{C}$ for $30 \mathrm{~s}$; and final incubation $72^{\circ} \mathrm{C}$ for $7 \mathrm{~min}$.

\section{Genomic characterization}

Amplification products were electrophoresed on a 1.5\% agarose gel against a $100 \mathrm{bp}$ DNA leader marker (Thermo Scientific) and visualized by UV irradiation and ethidium bromide staining (Sigma-Aldrich, Louis, MO, USA). Amplicons of the correct size were excised from the agarose gel and purified using the QIAQuick gel extraction kit (QIAgen, Valencia, CA, USA) according to the manufacturer's specifications for sequencing (1st BASE, Selangor, Malaysia). The percentage of identities and similarity scores of the viral gene sequences were calculated using DNASTAR Lasergene (DNASTAR, Inc., Madison, USA). The gene identities and similarities of two ASFV strains from Vietnam were compared with the reference sequences of ASFV strains from the National Center for Biotechnology Information (NCBI). 


\section{RESULTS AND DISCUSSION}

It has been indicated that $\mathrm{CD} 2 \mathrm{v}$ protein of ASFV is required for detecting the HAD phenotype and mediating the HAI serological groups [7]. Additionally, the analysis of $\mathrm{CD} 2 \mathrm{v}$ sequence is simple method for ASFV serotyping [6]. The first description of CD2v serogroups of ASFV based on 816 bq long fragment is reported in 2017 by Sanna [5] and this method has been applied successfully for ASFV serotyping [9]. In this study, two ASFV isolates from North Central Coast of Vietnam were used for viral isolation in combination with HAD test and a primer set to amplify the short fragment of CD2v gene was designed using Primer3 software (named as CV2v R1 and CD2v F1). Additionally, PCR primers developed by Sanna [5] with slight modification based on our previous results and GenBank databases for genotypes II were employed to establish a new analytic method for serotyping of ASFVs (Figure 1). Two field ASFV isolates, ASFV/VN/Pig/NA/1299 and ASFV/VN/Pig/TH/1238, were used to examine these primer sets. The HAD positive results and the success to amplify the short and long fragments of EP402R gene of ASFV/VN/Pig/NA/1299 (accession numbers MN711770) and ASFV/VN/Pig/TH/1238 (accession numbers MN711768) isolates by two primer sets were shown in Figure $2 \mathrm{~A}$ and $\mathrm{B}$.

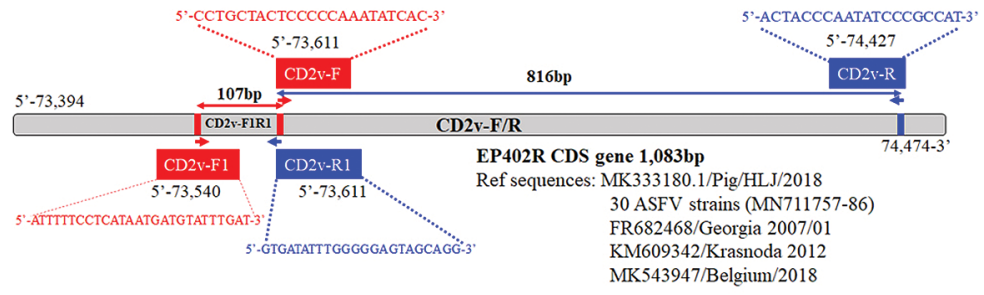

Figure 1. Represent the primer design to amplicon of short fragment (107 nucleotides) and long fragment (816 nucleotides) of EP402R gene coding for CD2-like protein. The ASFV strains Pig/HLJ/2018 in China, Georgia 2007/01 in Georgia, Krasnoda 2012 in Russia and Belgium/2018 in Belgium (Acc. number MK333180.1, FR682468, KM609342 and MK543947, respectively) and 30 ASFV strains isolated in Vietnam (accession numbers MN711757-86), indicated by red color were used as reference genomes.

It is demonstrated that serotyping based on EP402R gene sequences showed to be a useful and convenient tool when compared to hemagglutination inhibition (HAI) assay [5]. Some previous works indicated that the consideration when performing a vaccine design and development should be given to the fact that viruses within a serogroup provide cross-protection from challenge with viruses of the same serogroup. A recent study has found that ASFV isolates, clustered to serogroups 1,2 , or 4 , were recognized as genotype I group based on p72 gene sequences. The alignment of short fragments of 90 nucleotide sequences from 30 ASFV sequences in North Central region of Vietnam (accession numbers MN711757-86) and 68 reference sequences of well-known serogroups was shown in Figure 3. Interestingly, 


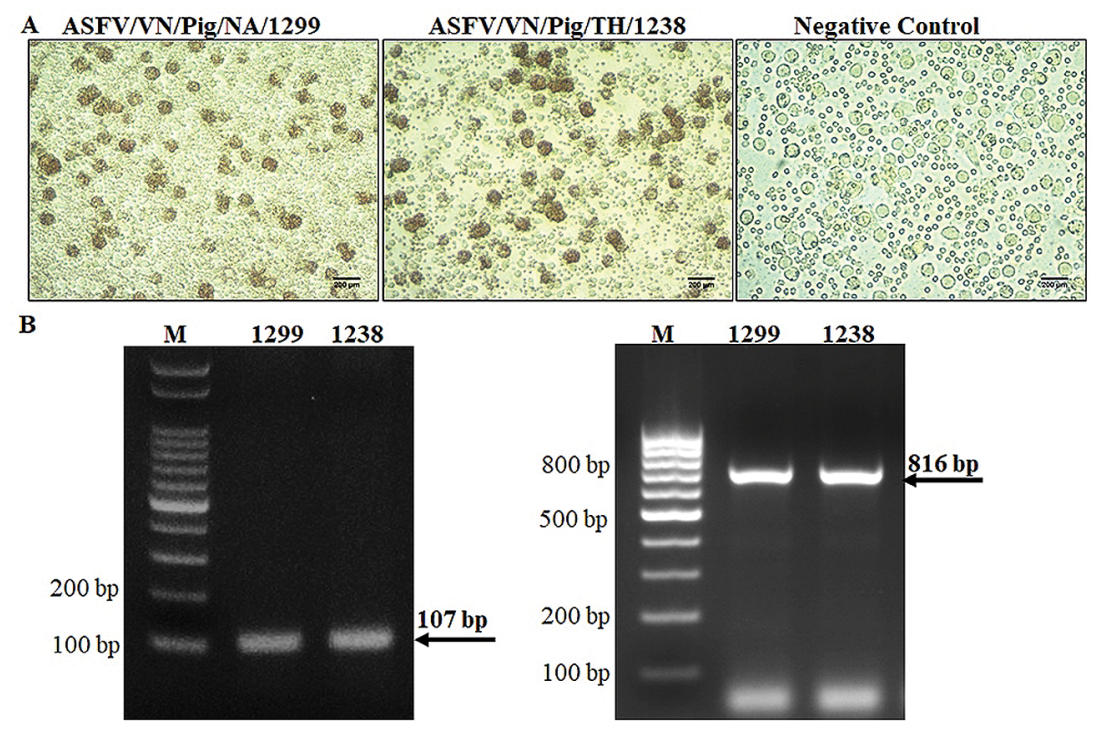

Figure 2. (A) Virus isolation is in combination with the Hemadsorption test in the culture

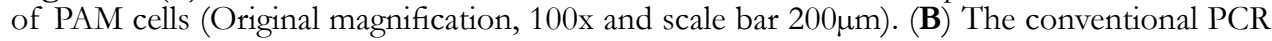
to amplify the short (107 nucleotides) and long (816 nucleotides) fragments of EP402R gene coding for CD2-like protein.

it is clear that a short fragment of EP402R genes is very typical for 8 serotype groups of ASFVs. Phylogenetic analyses of nucleotide sequences of EP402R gene encoding for CD2- like protein was further constructed using the neighbor-joining method with a bootstrap value of 1,000 in the MEGA7 program [12]. The results in Figure 4A and $4 \mathrm{~B}$ indicated an agreement exists between short fragment analysis (Figure 4B) and the previous method based on 816 nucleotide long sequences (Figure 4A) in which the two methods shares 22 nucleotides in the downstream sequences of 90 nucleotides short fragment. Additionally, ASFV serotyping based on 90 nucleotide short fragments is clearer and more specific when compared to long fragment analysis as seen in Figure 4. In previous studies, a good correlation for ASFV serotyping between phylogenetic analysis of EP402R gene coding for CD2-like protein and HAI serogrouping were observed and the information of ASFV serotypes is very necessary for vaccine design and development [6]. HAI assay is the golden method for ASFV serotyping. However, this method required a live virus, reference serum and may not apply in the cases of non-haemadsorbing ASF viruses. Additionally, ASFV antibodies may appear late or at low titre during infection, affecting directly to this assay [13-16]. Thus PCR based on sequencing method of EP402R gene encoding for CD2-like protein is good candidate and simple method for serotyping of ASFV [6]. Our results suggested that analysis of short fragments of EP402R gene is good tool for serotyping of ASFV strains circulating in Vietnam. 


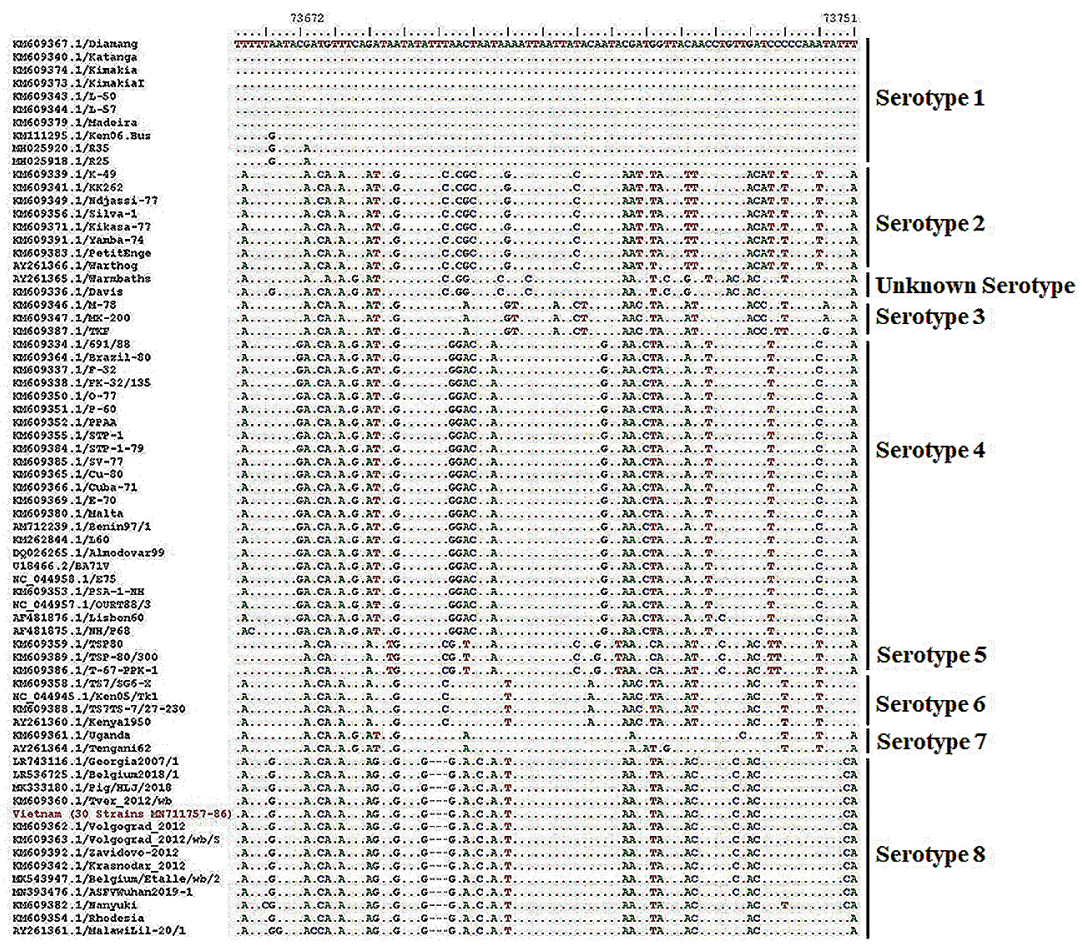

Figure 3. Alignment of the 90 nucleotide sequences of the EP402R genes in African swine fever virus isolated from the North Central Coast of Vietnam and some well-known references of ASFV strains.
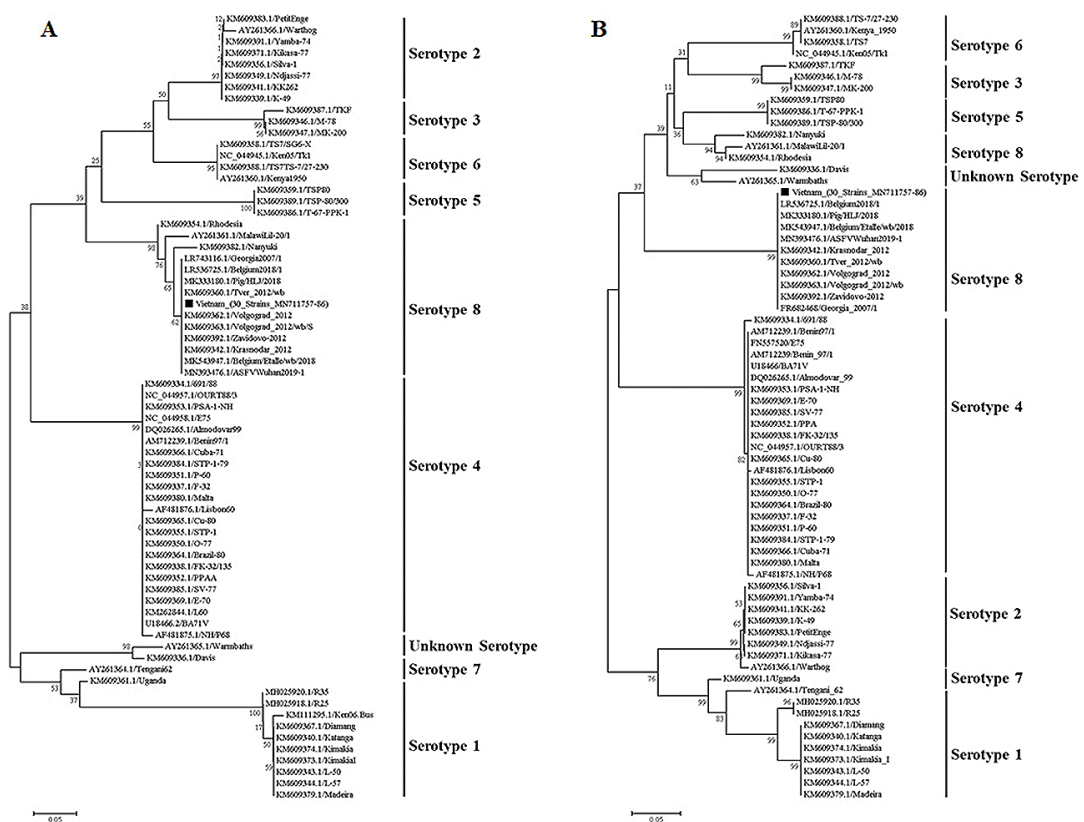
Figure 4. Phylogenetic analysis of the 90 nucleotide sequences (A) and 816 nucleotide sequences $(\mathbf{B})$ of EP402R gene encoding for CD2-like protein. The sequences of the EP402R gene coding for $\mathrm{CD} 2 \mathrm{v}$-like protein of representative ASF virus were downloaded from the NCBI database. The neighbor-joining method was used to construct phylogenetic trees using MEGA 7 software. Numbers along branches indicate bootstrap values $>80 \%$ (1,000 replicates). The black square indicates the ASF virus isolate from this study. Scale bars indicate nucleotide substitutions per site.

\section{CONCLUSION}

To our knowledge, the information of serogroups of ASFV is very important for vaccine development, as well as the strategy of vaccine use in the future. Taken together, our data suggested that phylogenetic analysis of 90 nucleotide sequences of EP402R gene amplified by CD2v R1/F1 primers is a useful and specific tool for serotyping of circulating ASFV strains when compared to the previous method using a long fragment of 816 nucleotides and well-known serotyping references based on HAI assays.

\section{Acknowledgments}

This work was supported by the Ministry of Science and Technology to Hoang Vu Dang (Project code: ĐTĐL.CN-75/19). The authors would like to thank Dr. Andrew G. Yersin of Kemin Industries, Inc. Scott Avenue Des Moines, IA 50317, USA, for English edition.

\section{Ethics approval and consent to participate}

The study was conducted in compliance with the institutional rules for the care and use of laboratory animals and using the protocol approved by the Ministry of Agriculture and Rural Development of Vietnam (TCVN 8402:2010).

\section{Availability of data and materials}

All sequences have been deposited to GenBank under accession numbers MN71175786 for CD2v genes.

\section{Authors' contributions}

T'TTTH, TAD, and DVH carried out the conceptuaxafion, molecular geneticstudies, participated in the sequence alignment, methodology, software, validaytion, investigation, anddrafted the manuscript. LDV, HVT, CTN, NTH and NTC participated in the design of the study,performed the data curation and helped to draft the manuscript. All authors read and approved thefinal manuscript. 


\section{Declaration of conflicting interests}

The author(s) declared no potential conflicts of interest with respect to the research, authorship, and/or publication of this article.

\section{REFERENCES}

1. Tran HTT, Truong AD, Dang AK, Ly DV, Nguyen CT, Chu NT, Nguyen HT, Dang HV. Genetic Characterization of African swine fever viruses circulating in North Central region of Viet Nam. Transbound Emerg Dis 2020.

2. Tran HTT, Truong AD, Ly DV, Vu TH, Hoang VT, Nguyen TC, Chu TN, Nguyen TH, Pham NT, Nguyen T, Yersin AG, Dang HV. Genetic Characterisation of African Swine Fever Virus in Outbreaks in Ha Nam Province, Red River Delta Region of Vietnam, and Activity of Antimicrobial Products Against Virus Infection in Contaminated Feed. Journal of veterinary research 2020, 64(2):207-213.

3. Tran HTT, Dang AK, Ly DV, Vu HT, Hoang TV, Nguyen CT, Chu NT, Nguye VT, Nguyen HT, Truong AD, Pham TN and Dang HV. An improvement of real-time PCR system based on probe modification is required for accurate detection of African swine fever virus in clinical samples in Vietnam. Asian-Australas J Anim Sci 2019.

4. Truong AD, Ly DV, Vu TH, Hoang VT, Nguyen TC, Chu TN, Nguyen HT, Nguyen TV, Pham NT, Tran HTT and Dang HV. Unexpected cases in field diagnosis of African swine fever virus in Vietnam: The needs consideration when performing molecular diagnostic tests. Open Veterinary Journal 2020, 10(2):189-197.

5. Sanna G, Dei Giudici S, Bacciu D, Angioi PP, Giammarioli M, De Mia GM, Oggiano A. Improved Strategy for Molecular Characterization of African Swine Fever Viruses from Sardinia, Based on Analysis of p30, CD2V and I73R/I329L Variable Regions. Transbound Emerg Dis 2017, 64(4):1280-1286.

6. Malogolovkin A, Burmakina G, Titov I, Sereda A, Gogin A, Baryshnikova E, Kolbasov D. Comparative analysis of African swine fever virus genotypes and serogroups. Emerg Infect Dis 2015, 21(2):312-315.

7. Malogolovkin A, Burmakina G, Tulman ER, Delhon G, Diel DG, Salnikov N, Kutish GF, Kolbasov D, Rock DL. African swine fever virus CD2v and C-type lectin gene loci mediate serological specificity. The Journal of general virology 2015, 96(Pt 4):866-873.

8. Ge S, Li J, Fan X, Liu F, Li L, Wang Q, Ren W, Bao J, Liu C, Wang H et al. Molecular Characterization of African Swine Fever Virus, China, 2018. Emerg Infect Dis 2018, 24(11):2131-2133.

9. Kim SH, Kim J, Son K, Choi Y, Jeong HS, Kim YK, Park JE, Hong YJ, Lee SI, Wang SJ et al. Wild boar harbouring African swine fever virus in the demilitarized zone in South Korea, 2019. Emerg Microbes Infect 2020, 9(1):628-630.

10. OIE. African swine fever. Manual of Diagnostic Tests and Vaccines for Terrestrial Animals 2012, Chapter 2812012.

11. Li L, Wang Q, Ge S, Liu Y, Liu C, Liu F, Hu Y, Li J, Bao J, Ren W et al. Infection of African swine fever in wild boar, China, 2018. Transbound Emerg Dis 2018.

12. Kumar S, Stecher G, Tamura K. MEGA7: Molecular Evolutionary Genetics Analysis Version 7.0 for Bigger Datasets. Mol Biol Evol 2016, 33(7):1870-1874. 
13. Malmquist WA. Serologic and immunologic studies with African swine fever virus. Am J Vet Res 1963, 24:450-459.

14. Vigario JD, Terrinha AM, Bastos AL, Moura-Nunes JF, Marques D, Silva JF. Serological behaviour of isolated African swine fever virus. Brief report. Arch Gesamte Virusforsch 1970, 31(3):387-389.

15. Ruiz Gonzalvo F, Carnero ME, Caballero C, Martinez J. Inhibition of African swine fever infection in the presence of immune sera in vivo and in vitro. Am J Vet Res 1986, 47(6):1249-1252.

16. Ruiz-Gonzalvo F, Coll JM. Characterization of a soluble hemagglutinin induced in African swine fever virus-infected cells. Virology 1993, 196(2):769-777.

\section{BRZA SEROTIPIZACIJA VIRUSA AFRIČKE KUGE SVINJA ZASNOVANA NA ANALIZI KRATKIH FRAGMENATA EP402R GENA KOJI KODIRA CD2-LIKE PROTEIN}

TRAN Ha Thi Thanh, TRUONG Anh Duc, LY Duc Viet, HOANG Tuan Van, NGUYEN Chinh Thi, CHU Nhu Thi, NGUYEN Huyen Thi, DANG Hoang Vu

Prvi potvrđen slučaj afričke kuge svinja (ASF) u Vijetnamu bio je zvanično prijavljen u februaru 2019. godine. Do danas, ASF virus (ASFV) je detektovan u 63 provincije Vijetnama. Radi boljeg razumevanja potencijalne uloge EP402R gena u grupisanju ASFV serotipova, analizirano je trideset ASFV sekvenci EP402R gena (pristupni brojevi: MN711757-86) poreklom iz Centralne severne obale Vijetnama i 68 referentnih uzoraka serotip grupa koji su dobro poznati iz prethodnih studija. Interesantan je bio nalaz da je kratak fragment od 90 nukleotida bio tipičan za 8 seroloških grupa ASF virusa. Dizajniran je set prajmera sa ciljem amplifikacije kratkih fragmenata (90 nukleotida), korišćenjem Primer3 programa, a za uspostavljanje jednostavne metode serotipiziranja ASFV. Rezultati ukazuju da je filogenetska analiza kratkih fragmenata (90 nukleotida) EP402R gena je veoma specifična i predstavlja korisnu metodu serotipizacije ASFV u poređenju sa prethodno opisanim metodama koje su koristile duge fragmente (816 nukleotida) ovog gena kao i dobro poznate referentne serotipove dobijene metodom inhibicije hemadsorbcije. 